\title{
Attitudes of Health Professionals and Primary School Staff towards the Separation of Children from families and Foster Care
}

1 Suzana Vidović Vondra

1 Sanja Narić

1 Ana Pavelić Tremac

1 Josipa Kurtović

1 Neuropsychiatric Hospital „dr. Ivan Barbot”, Popovača, Croatia

Article received: 23.10.2019.

Article accepted: 03.02.2020.

\section{DOI: $10.24141 / 2 / 4 / 1 / 3$}

\section{Author for correspondence:}

Suzana Vidović Vondra

Neuropsychiatric Hospital „dr. Ivan Barbot”

Vinogradska 55, Popovača, Croatia

E-mail: suzana.vidovicvondra@gmail.com

Keywords: attitudes, foster care, separation of children, mental healthcare professionals, school professionals

\section{Abstract}

In Croatia, the process of deinstitutionalization of childcare is underway, and it should increase the placement of children in non-institutional forms of care such as foster care. The aim of the study was to examine attitudes towards foster care and child separation among school and adult mental health professionals.

The sample consisted of 159 respondents (employees of elementary schools in Kutina, Popovača and Velika Ludina and employees of the Neuropsychiatric Hospital "Dr. Ivan Barbot" in Popovača). The survey covered all relevant sociodemographic variables, and the Scale of Attitudes Towards Separation of Children from Family and the Attitudes Towards Foster Care Scale were used to examine attitudes [Kamenov, Sladovic Franz \& Ajdukovic, 2005].

In the sample examined, attitudes to foster care and separation are slightly positive, indicating that there is plenty of room for activities aimed at empowering these views. If further attitudes are to be strengthened, therefore the population of potential future foster parents is also expected to expand.

It is important to highlight the role of healthcare professionals involved in the mental health care of foster children and to consider their role in modifying general attitudes towards foster care for children and their role in building an optimal foster care system. 


\section{Introduction}

Currently in Europe there is a process of deinstitutionalization of childcare underway, which means restructuring of institutional care, developing, and strengthening alternative care. It is encouraged by research that growing up in institutions is the least beneficial solution for a child and a serious threat to society as it reduces its resources (1). Children who are growing up in foster families have better mental health indicators, better social support, and lower levels of perceived daily stress compared to children living in residential care $(2,3,4)$. In terms of developing and strengthening alternative forms of childcare, a lot is being invested in development of foster care, reduction of the number of children placed in institutions, reduction of the size of institutions and developing family foster homes (the development of professional foster families as solutions for children who need special treatment). Furthermore, various types of foster care are developed - short-term, longterm, in crisis, foster care before adoption, foster care for mother and baby, foster care for families etc. (1). There is strong evidence that children in kinship foster care have fewer behavioral problems $(3,4,5)$ and fewer mental health problems $(3,6)$ than children in non-kinship foster care.

Children age 6 or older in kinship care are less likely to have behavioral problems than peers in non-kinship foster care $(4,5)$ infants in kinship care are also less likely to have developmental delays (7).

In Croatia, in 2014, the ratio of institutional care to non-institutional care (foster care and family-type homes) was $39.6 \%$ versus $60.4 \%$, while the aim for the year 2016 was to reach $20 \%$ to $80 \%$ (8). With regard to the ratio of children placed in institutions and foster homes, the situation in Croatia is less favorable than in Western European countries (1). Childcare homes in Croatia are too large and the number of children should be reduced, especially for children under 7 years of age. Most foster parents are over 50 years of age, and foster care is not evenly developed in different areas of Croatia. Therefore, activities to promote foster care need to be undertaken, especially to mobilize younger citizens and those living in parts of Croatia where foster care is less represented (8). It is necessary to raise the level of preventive measures in relation to families and children at risk of separation. The Foster Care Act, which came into force on January 1, 2019, professionalizes foster care and introduces special foster care for children in need of special treatment (9). The new law thus brings about positive changes in relation to the foster care regulation, which does not, however, guarantee social changes in attitudes towards foster care. Attitudes, in turn, are an important psychological component that drives our behavior and choices.

In Croatia, but also more broadly, there is not much research on attitudes of experts, as well as of the public, towards child separation and foster care. The conducted research in our area shows a slightly positive attitude towards both issues $(10,11)$. Experts who participate directly in decision-making processes regarding separation and foster care show a bit more positive attitude towards separation than people in the general population, and somewhat more negative towards foster care (10). A positive attitude towards separation of children from families at risk is not necessarily linked to a positive attitude towards foster care as the best solution for these children, and obviously there is still a lot of investment to be done in raising the quality of foster care so it can be recognized as the best choice for childcare (10).

Investigating public attitudes about separation and foster care is also important in terms of planning and implementing activities to recruit future foster carers.

\section{Background}

Examining the attitudes of the general population about foster care is certainly one of the necessary initial steps to plan and implement these activities.

According to Pennington (12), attitude is one of the basic concepts for understanding social life, and one of the basic concepts of social psychology in general. By modern definition, an attitude can be defined as an acquired, relatively permanent and stable organization of positive or negative emotions, values and reactions to an object (12).

No other psychic trait influences events in human society, nor is as influenced by society itself, as atti- 
tudes are. For that reason attitudes are an important part of a person's personality. Attitudes are acquired, shaped and changed in the process of social development of an individual, and are formed based on different types of learning (gaining experience). They affect human memory, perception, thinking, and actions, they can foster love or hate, provoke social conflict, or resolve conflicts (13).

According to the three-component model, attitude is the product of cognitive, emotional and behavioral processes and has cognitive, emotional and behavioral reactions to an object. This model of attitude structure is also called the ABC model (affect, behavior, cognition) (14).

Knowledge, in addition to perceptions of the object, contains an evaluation and includes a positive or negative validation, evaluation and judgment on the characteristics of the object. The emotional component contains the emotional attitude towards the object of the attitude, that is, the experience that the object is pleasant and attractive or unpleasant and repulsive. If the object of the attitude is perceived as pleasant and attractive, a positive emotional relationship will form. On the other hand, if the object is perceived as unpleasant and repulsive, the emotional relationship will be negative. Emotional saturation gives the attitude special strength and stability (15). The behavioral component is manifested in the willingness to act towards the object of the attitude. Attitudes can be positive or negative, so a positive attitude is manifested in the desire to support, assist and protect the object of the attitude, while negative attitude in that the object is avoided, disabled or attacked. If the person has more information about the object and more contacts with the object then the attitude is more favorable.

Attitudes thus affect attention and presentation, perception and judgment, and elaboration and memory. The relationship between attitude and behavior is as strong as attitude and behavior correspond in their specificity or association, and in which these simple aspects, functions and components of attitude are salient at the time that attitude and behavior are measured. Personality variables also influence the relationship between attitude and behavior. As such, attitudes can be examined, and based on the results, obtained conclusions and predictions can be made about the epidemiological status and the trend of changes in relation to the phenomenon with which we associate attitudes.
In Croatia, but also more broadly, a small number of surveys have been conducted on the attitudes of experts, as well as of the public towards child separation and foster care. The conducted research in our area shows a slightly positive attitude towards both issues $(10,11)$. Experts who participate directly in decision-making processes regarding foster care and foster care show a more positive attitude towards separation than individuals in the general population, and somewhat more negative towards foster care (10), indicating that these are two independent cognitive assessments. A positive attitude towards the separation of children from families at risk is not necessarily linked to a positive attitude towards foster care as the best solution for these children, and obviously there is still a lot of investment to be done in raising the quality of foster care to be recognized as the best choice for separating children (10).

Research into attitudes of general public towards separation and foster care is also important in terms of planning and implementing activities to recruit future foster parents. Bearing in mind that attitudes influence behavior, the implementation of activities aimed at changing attitudes should also have an effect on increasing the number of potential future foster parents. In Croatia, foster carers, as already stated, are mostly women over 50 years of age, of lower and secondary education, women, rural residents (16). In this sense, activities should be carried out in order to attract potential foster carers of younger age, higher education, and also urban residents. Examining the attitudes of the general population about foster care is certainly one of the necessary initial steps to plan and implement these activities. Bearing in mind that attitudes influence behavior, the implementation of activities aimed at changing attitudes should also have an effect on increasing the number of potential future foster parents.

People employed in educational work with children are often among the first to detect children whose rights and health are endangered within the family, and often are initiators or participants in the process that ultimately leads to decisions about the need for separation of children. In their workplace, they often come into direct contact with children separated from their families or foster children, and their attitudes towards foster care and separation may certainly affect their professional relationship with children and foster parents.

Healthcare professionals, as well as nurses, meet with members of different groups to whom they 
have certain opinions and attitudes and behave in a certain way. Pediatric nurses are also more likely to encounter foster children and it is important to be aware of the attitudes and potential prejudices they may have towards children, as well as their foster parents. Foster children may also have some specific difficulties and concerns, that they may have during their hospital stay or examination. It is important to know how to respond in such situations, to be empathetic, to support both children and foster parents. Similarly, health professionals working in educational institutions can help educate peers (kindergartens, schools) who, due to ignorance, may have prejudices or behave inappropriately towards such children.

A special group of health professionals are those involved in mental health care of children and adolescents. A nurse in the mental healthcare system, with her attitude and empathetic capacity, can greatly help build a positive attitude towards all relevant caregivers of vulnerable groups, which is extremely important in the process of destigmatization of children with mental disorders. Also, by promoting mental health, a nurse participates in the primary and secondary prevention of further development and complication of psychiatric disorders in foster children.

\section{Aim}

This study examined whether there is a difference in attitudes toward foster care and separation of children from their families, between professionals working with children within the educational system and professionals working in the adult mental healthcare system.

\section{Methods}

The sample consisted of 159 respondents, mostly female (80.5\%). The average age was 41 years $(M=41.13$, $S D=10.750)$. Most of them live in a smaller city (66.7\%) and are married. Dominant education level is high
(51.6\%), and $44 \%$ of the respondents are directly involved with children within current workplace. Almost a third of respondents are parents, and $84.9 \%$ of respondents consider their earnings to be average. The average length of service is 18 years ( $M=18.48 ; S D=11.561)$.

A sample of respondents employed in education field was made up of elementary school staff (classroom teachers, subject teachers, professional assistants) in Kutina, Popovača and Velika Ludina, with $39.6 \%$ of respondents $(N=63)$. A sub-sample of the healthcare employees were staff in the Neuropsychiatric Hospital "Dr. Ivan Barbot” in Popovača (nurses , first-year nurses, masters/ nurses, social workers, psychologists, social pedagogues, doctors, carers, occupational therapists, professional referents), 58.5\% ( $\mathrm{N}=93)$.

The Scale of Attitudes Towards Separation of Children from Family and the Attitudes Towards Foster Care Scale were used in which the respondents expressed their attitude on a 5-point Likert scale on each statement, with number 1 indicating complete disagreement and number 5 indicating complete agreement.

The Scale of Attitudes Towards Separation of Children from Family (5) consists of 20 statements (7 positive and 13 negative). Formation of the total result, which is achieved by summing the answers on individual statements, is preceded by the transformation of the answers on negative statements. The possible range of results is from 20 - extremely negative attitude to 100 - extremely positive attitude, and the mean value is 60 - neutral attitude towards separating children from their family. In addition to the total result, it is possible to calculate the result on factors that are integral to the total attitude towards the separation. The Scale of Attitudes Towards Separation of Children from Family thus measures four subscales: Benefit of separation, Cruelty of separation, Unpromising prospect of a separated child, and Inviolability of the rights of a biological family. The scale reliability test obtained a high coefficient of internal consistency ( $\alpha=0.85)$ and one overall result can be obtained indicating the intensity of attitudes towards the separation of children from the family.

The Attitudes Towards Foster Care Scale (5) consists of 22 statements (11 positive and 11 negative). Formation of the total result, which is achieved by summing the answers on individual statements, is preceded by the transformation of the answers on negative statements. The possible range of results is from 22 - extremely negative attitude to 110 - extremely positive 
attitude, and the mean is 66-neutral attitude towards foster care. In addition to the total score, it is possible to calculate the score on factors that are integral to the overall attitude towards foster care, and measures four subscales: Negative aspects of foster care - Child exploitation, Foster care as a reflection of love for children, Advantages of foster care compared to institution, and Lack of expertise compared to institutions. The scale reliability test yielded a high internal consistency coefficient $(\alpha=0.91)$ and one overall result indicating the intensity of foster care attitudes was obtained. An electronic version of the questionnaire used in the survey was distributed to primary school staff. A part of the staff of the Neuropsychiatric Hospital "Dr. Ivan Barbot "completed the paper version of the questionnaire, while the second part was passed the electronic version of the questionnaire. The questioning was completely anonymous. Participants completing the paper-pen version of the questionnaire completed the questionnaire in groups. The data was collected between the beginning of June and the end of August 2018.

\section{Results}

The mean of the recoded total scores of the respondents on the Scale of Attitudes Towards Separation of Children from Family is 70.01. When considering the possible range of the total score from 20 (extremely negative attitude) to 100 (extremely positive attitude) while a neutral attitude towards child separation is a value of 60 , we can state that the respondents have a slightly positive overall attitude towards child separation from the family. Table 1 shows the average values at the level of the whole sample for attitudes towards the separation of children from the family.

Table 1 shows that the respondents the least agree with the position covered by factor number 6 , with the statement that the only valid reason for separating children is the threat to their lives. They have an unspecified or neutral attitude towards the experiencing professionals who separate children from families as determined and courageous persons. In this study, respondents expressed the highest agreement with factors 4, 9, and 20. Most respondents do not think that separated children will not know how to start and care for their families, and do not perceive separated children as a burden to society while separation is considered a good measure of protection of the abused and neglected child.

The means on particular factors of the Scale of Attitudes Towards Separation of Children from Family indicate that the respondents have the most positive attitude on Unpromising prospect of a separated child subscale, which means that on average they do not think that separated children are doomed to a non-perspective future (Graph 1).

The mean of the total recoded results of the respondents on the Attitudes Towards Foster Care Scale is 76.01. When considering the possible range of the total score from 22 (extremely negative attitude) to 110 (extremely positive attitude) while a neutral attitude towards foster care represents a value of 66 , we can state that these respondents have a slightly positive overall attitude towards foster care.

Table 2 shows that, on average, respondents have a neutral attitude towards experiencing foster parents as people who only care for financial benefits, the lack of expertise in foster families, and the warmer attitude of foster parents towards children compared to professionals. Respondents express the most positive attitudes towards factor 20 which means that they most agree with experiencing foster parents as greedy people.

Based on the means of the respondents' results on particular factors of the Attitudes Towards Foster Care Scale, it can be concluded that the respondents have a neutral attitude on the first three subscales, while the average attitude is negative on the Lack of expertise compared to institutions subscale. Respondents consider, on average, that foster carers lack expertise in relation to institutions.

Statistically significant differences were obtained in the overall attitude towards child separation as well as in the individual components of attitude towards separation between respondents employed in education and health field. Respondents employed in education have a more positive overall attitude $(t=2.241 ; p=0.027)$ towards the separation of children compared to respondents employed in health care. Education field employees experience separation as more beneficial ( $\mathrm{t}=3.486 ; p=0.001)$ and find it less cruel ( $\mathrm{t}=2.507 ; p=0.013)$ than those employed in health care. Persons employed in education and health care did not differ in the attitudes on the 


\section{Table 1. Means of non-recoded responses to individual factors on the Scale of Attitudes Towards} Separation of Children from Family

The Scale of Attitudes Towards Separation of Children from Family

1. The timely separation of the child from the family is in the child's best interests.

2. No one has the right to take away children from their parents.

N M SD

2. No one has the right to take away children from their parents.

$1593.49 \quad 0.892$

$\begin{array}{lll}158 & 3.51 & 0.865\end{array}$

3. After separation from the family, the child will lose all friends and it is better for child to stay in the family.

$\begin{array}{lll}158 & 3.76 & 0.744\end{array}$

4. Children separated from the family will not know how to start a family and take care of it. $\quad \begin{array}{llll}158 & 4.00 & 0.608\end{array}$

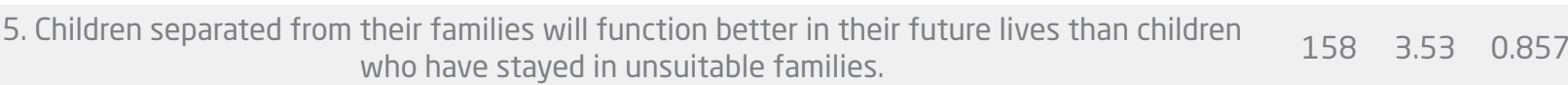

6. The only justifiable reason for separation is the threat to the life of the child. $\quad \begin{array}{lll}158 & 2.89 & 0.975\end{array}$

$\begin{array}{lllll}\text { 7. Separation is the worst possible solution for a child. } & 157 & 3.55 & 0.930\end{array}$

8. A separated child is lonely and distressed.

$\begin{array}{lll}158 & 3.60 & 0.829\end{array}$

9. Separation is a good measure to protect an abused and neglected child. $\quad \begin{array}{llll}157 & 3.93 & 0.690\end{array}$

10. A separated child is given more opportunities for successful development. $\quad \begin{array}{lllll}157 & 3.57 & 0.709\end{array}$

11. Separation from the family is a cruel act against the child. $\quad \begin{array}{lllll}154 & 3.36 & 0.928\end{array}$

12. By separating from the family, the children are saved. $\quad \begin{array}{llll}157 & 3.45 & 0.771\end{array}$

13. Separated children have a better future $\quad \begin{array}{llll}157 & 3.30 & 0.711\end{array}$

14. A child is always better off in biological than in any other family. $\quad \begin{array}{lllll}158 & 3.37 & 0.833\end{array}$

15. Experts who separate children from their families and are not real experts. $\quad \begin{array}{lllll}158 & 3.58 & 0.839\end{array}$

$\begin{array}{lllll}\text { 16. By separating children from the family we also break their connection with the wider family, } & 158 & 3.28 & 0.822\end{array}$

$\begin{array}{lllll}\text { 17. Separating a child from the family does nothing good for that child because the state does } & 158 & 3.28 & 0.789\end{array}$

18. Separation from family is bad for a child. $\quad \begin{array}{llll}158 & 3.32 & 0.838\end{array}$

19. The experts who separate children from the family are determined and courageous. $\quad \begin{array}{rrrr}158 & 3.01 & 0.782\end{array}$

20. Separated children are only a burden on society. $\quad \begin{array}{llll}158 & 4.11 & 0.648\end{array}$

Bold - negative statements that are recoded / transformed when calculating the total attitude

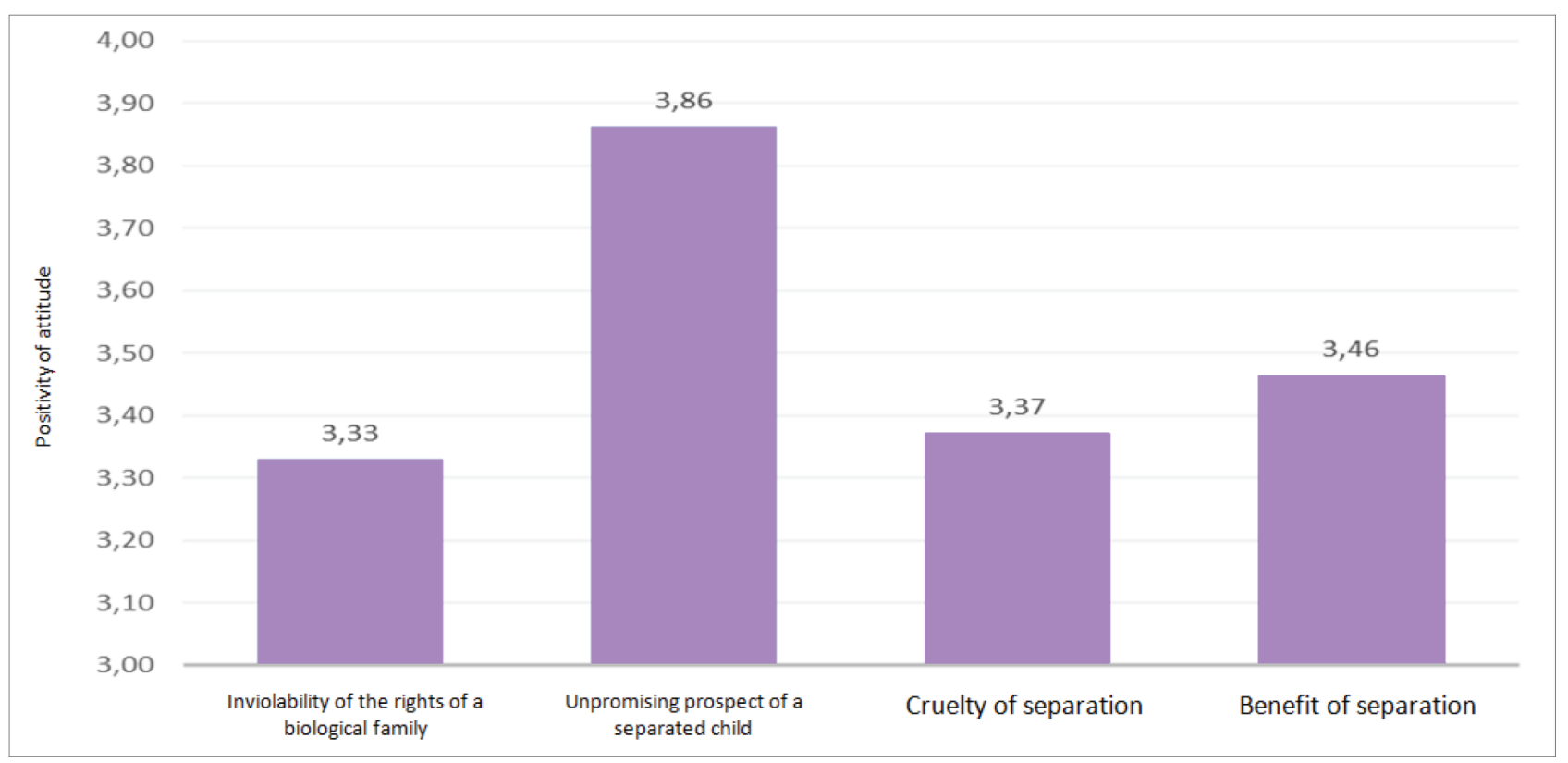

Graph 1. Means of non-recoded scores on individual factors of the Scale of Attitudes Towards Separation of Children from Family 


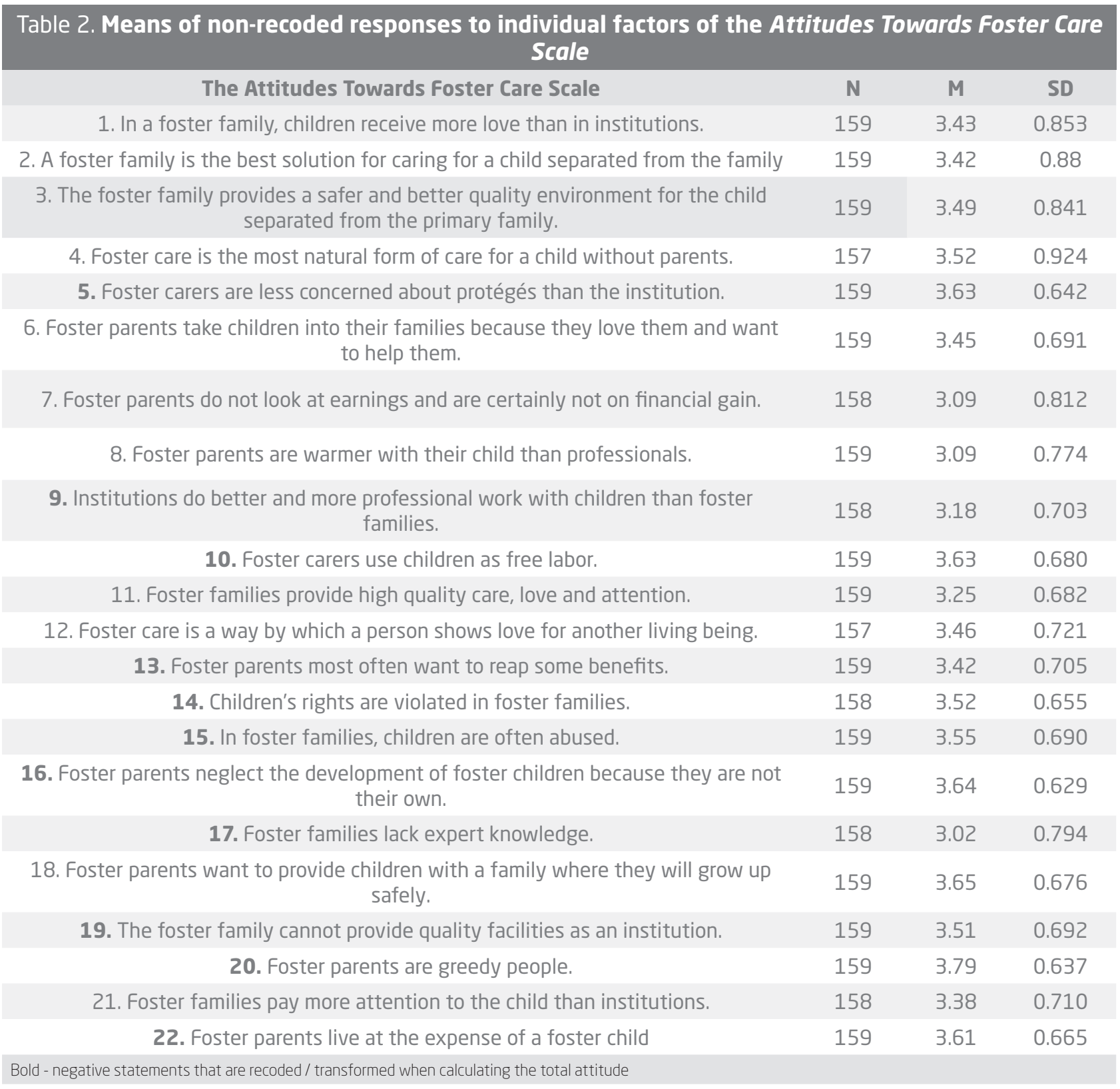

Inviolability of the rights of a biological family subscale ( $\mathrm{t}=-0.741 ; p=0.460)$ and the Unpromising prospect of a separated child subscale ( $\mathrm{t}=1.441 ; p=0.152)$.

Statistically significant differences were found in the overall attitude towards foster care as well as in the individual components of attitudes towards foster care between the respondents employed in education and health.

Respondents employed in education have more positive overall attitude towards foster care $(t=5.336$; $p=0.000$ ) than respondents employed in health care. Educational employees experience a lower presence of Negative aspects of foster care - child exploitation in foster care ( $\mathrm{t}=3.748 ; p=0.000)$, experience Foster care as a reflection of love for children to a greater degree $(t=5.707 ; p=0.000)$, and consider more positive the Advantages of foster care over an institution ( $t=5.780$; $p=0.000$ ) in comparison with respondents employed in health care. Employees in education and health care have a similar ( $\mathrm{t}=1.775 ; p=0.078$ ) negative attitude on Lack of expertise compared to institutions subscale. 


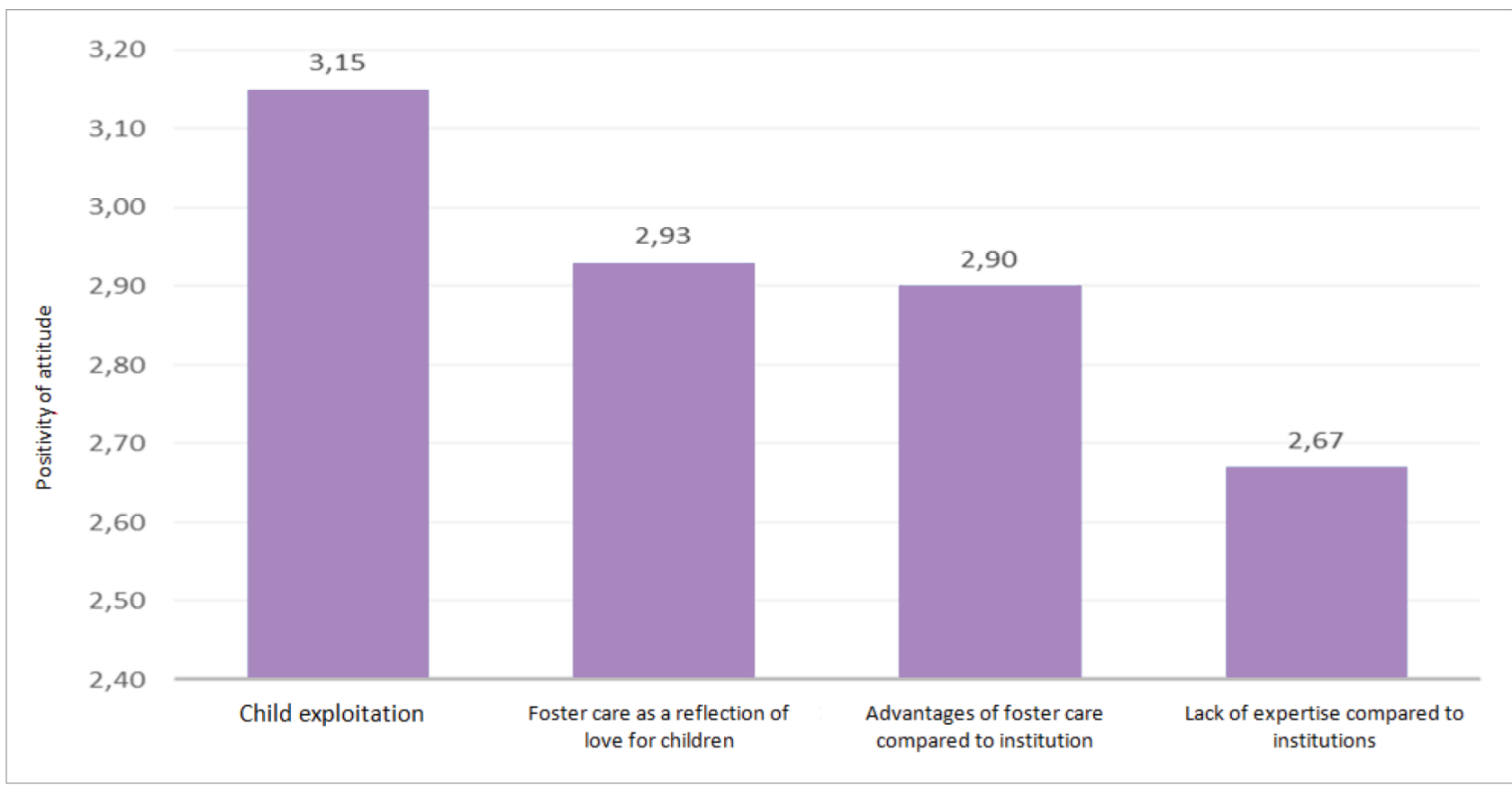

Graph 2. Means of respondents' non-recoded responses to particular factors of the Attitudes Towards Foster Care Scale

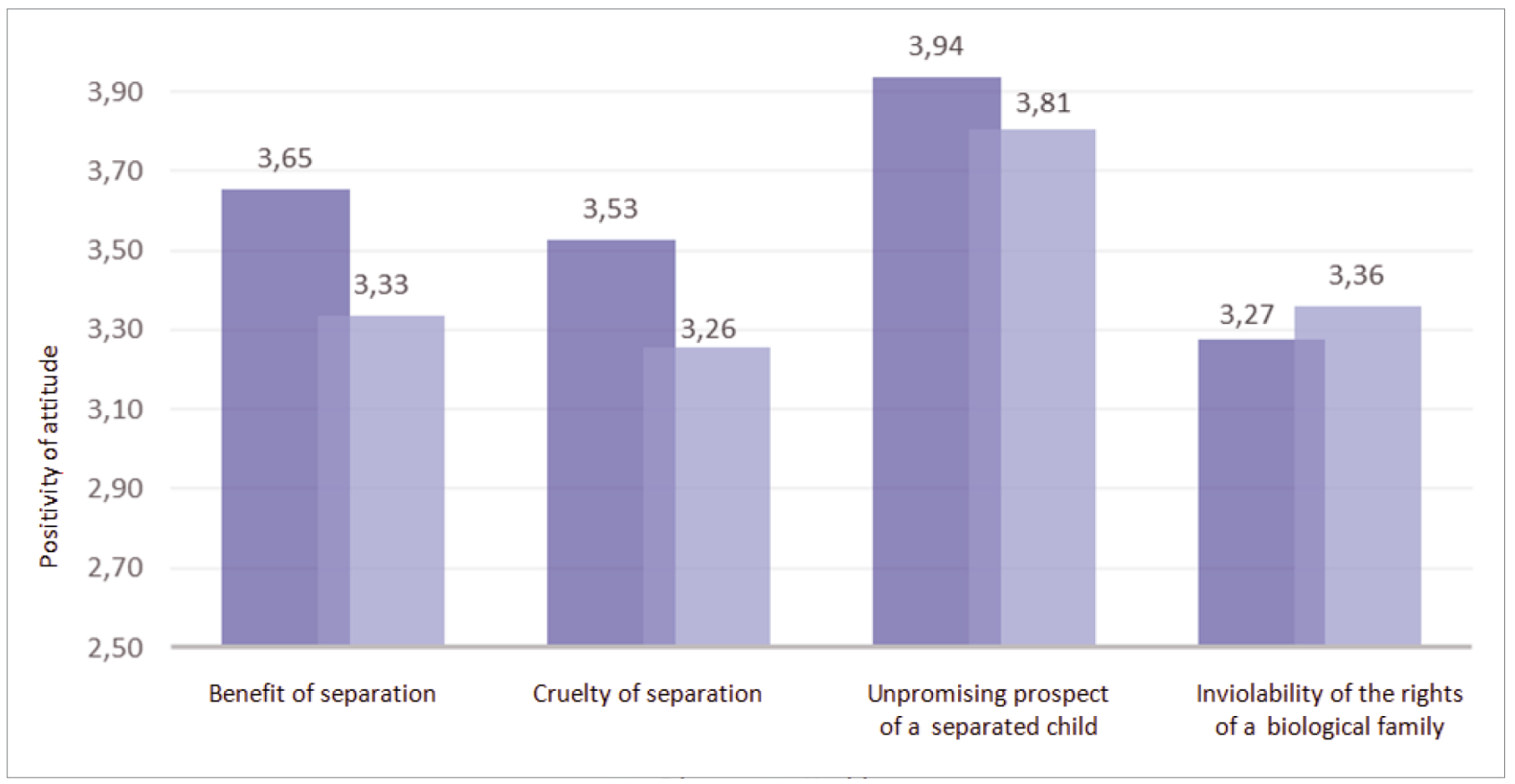




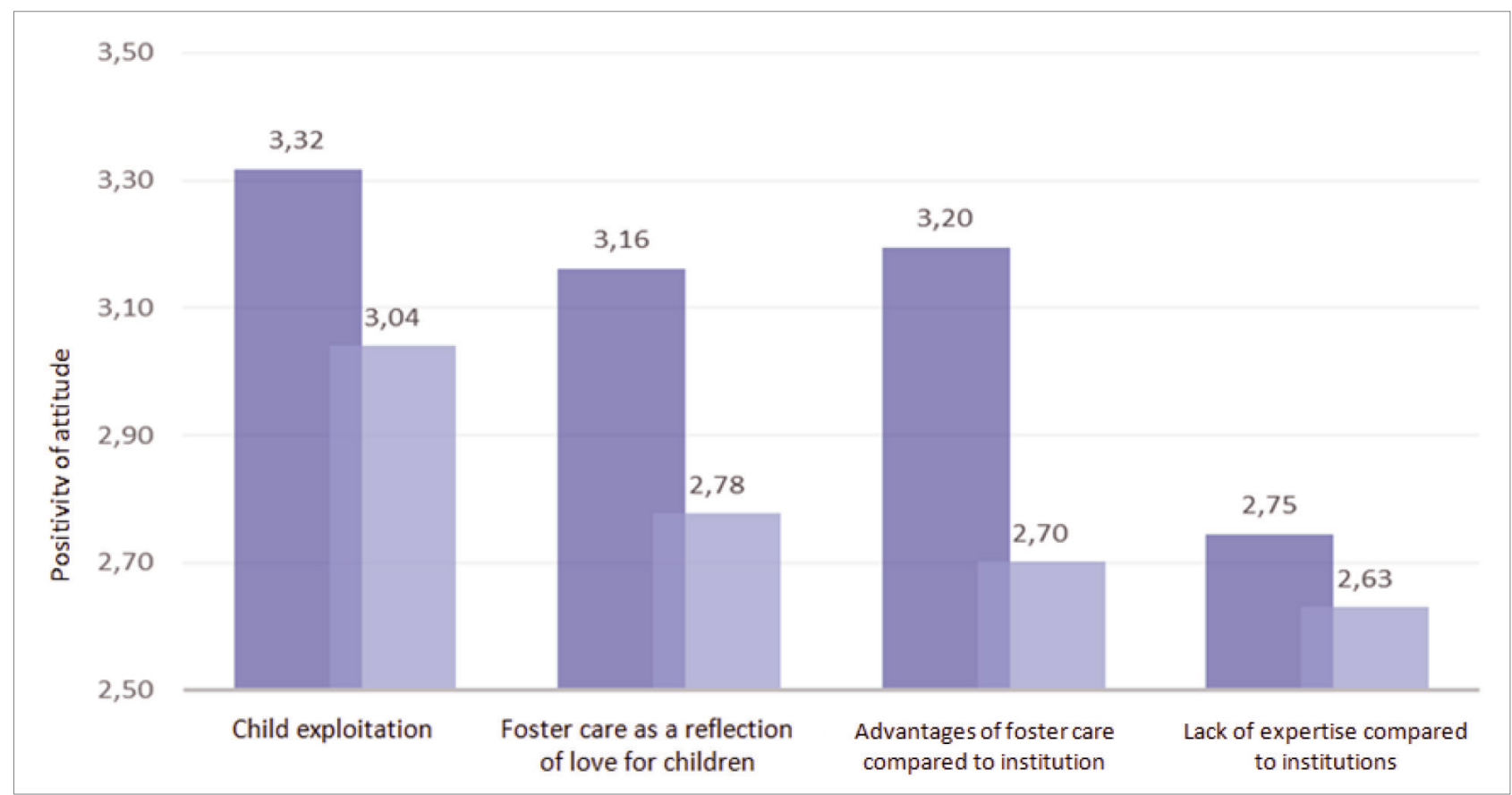

Graph 4. Differences on the Attitudes Towards Foster Care Scale between respondents employed in education and health care

\section{Discussion}

Respondents in this study showed a slightly positive overall attitude towards foster care and separation of children from the family. They exhibit slightly less variability (dispersal of individual responses) in their attitudes towards separation compared to attitudes towards foster care. In other words, their attitudes are more stable, that is, respondents have similar attitudes. When it comes to the individual components of attitudes towards foster care, respondents differ the least in attitudes towards Advantages of foster care over an institution subscale. On the other hand, they differ most in attitudes towards the benefits of foster care compared to institutions. When it comes to individual components of attitudes towards separation, the greatest agreement is expressed in attitudes towards the Unpromising prospect of a separated child and the Benefits of separation, and least in attitudes towards the Inviolability of the rights of the biological family.

Similar results in terms of a slightly positive attitude towards both tested objects were obtained by Ka- menov, Franz Sladović and Ajduković on a sample of social system experts and general population (10). This sample could be considered, for comparison, as a sample from the general population, since they are people who do not participate directly in the foster care process or in the process of separating children from the family. On average, the respondents have the most positive attitude towards the future of separated children and do not think that separated children are doomed to an unpromising future. On average, they believe that foster parents lack expertise compared to institutions. Furthermore, similar results were obtained in the study of attitudes of social services professionals towards foster care, which show that as many as $73.2 \%$ of experts agree with the claim that foster families lack expert knowledge (11). Research on foster parents' attitudes and selfassessment about their own education has yielded different results. Thus, Ajduković et al. (11) find in their study of 79 foster parents, that just under twothirds of respondents felt they had sufficient knowledge of their job. Žižak (16) cites a study of The Puls Agency on the state of foster care in Croatia, which shows that $38 \%$ of respondents are satisfied with the education they receive as a way of preparing for the foster care, while $33 \%$ believe that with the 
education they neither gained, nor lost anything. The Sirius Center in Croatia was the leader of the project "Competence Development for Carers and Educators of Children in Foster Care in the Context of Transition from Institutional to Community Based Care", which ran from 2014 to 2016. Within the project an analysis of needs for additional training of assistant educators, caregivers and foster parents was made. Particular focus was put on transversal skills which include: working with children with behavioral and learning disabilities, coping with stress and overload, working with children to develop a positive outlook, motivating children for school, skills in the field of communication, establishing and maintaining relationships, social skills, values and attitudes, and successfully coping with change and stress (17). This analysis has put forward proposals for improving existing models of foster care, according to which foster parents in Croatia should receive more frequent training, workshops and thematic lectures by experts, the system should provide more accessible practical psychological counseling when problems in foster care arise, organize meetings and facilitate the exchange of experience, provide psychological assistance, arrange for more training in the field of developmental difficulties of children and child behavior, ensure the availability of support and supervision groups and the possibility for foster parents to become involved. Looking at these recommendations, it seems that there is still much room for improvement in foster care education in Croatia, in which nurses involved in the child mental healthcare system certainly play their role as described in the introduction.

Respondents employed in education have a more positive overall attitude towards foster care; they experience there is less presence of child exploitation in foster care, they see foster care as a reflection of love to a greater degree, and find that foster care has more advantages than institutions, compared to healthcare professionals working in adult mental health care. Respondents employed in education and those in health field have the same view at the lack of foster parents' expertise compared to institutions.

The respondents employed in education have a more positive overall attitude towards the separation of children than the respondents employed in health care. Education employees experience more benefits in separation and find it less cruel than those employed in health care. Respondents employed in education and those in health field look equally at inviolability of the rights of a biological family and the unpromising prospect of a separated child.

Kamenov et al. (10) found differences in attitudes between social service professionals and the general population. Experts had a more negative attitude towards foster care and a more positive attitude towards child separation. To a lesser extent, they viewed foster care as a reflection of love, and they perceived significantly more that foster parents lacked expertise in comparison to institutions. The authors explained the more positive attitude of experts towards separation by the theory of cognitive dissonance according to which experts and decision makers about separation have to adapt their attitudes to their behavior. In this study, people employed in education have a more positive attitude towards both foster care and separation from those employed in the adult mental health field. Education employees, unlike adults in the adult mental health sector, are in intense contact with a large number of children. They are likely to be more aware of a threat to the child rights and of various other circumstances that otherwise lead to the separation of children. They may also be more educated on child rights issues and more likely to witness the consequences of inadequate parental care on children's functioning. Due to all the above, it is expected that, given the more realistic extent of harm when it comes to violations of the rights and health of children, education field employees will also have a more positive attitude towards the need to separate vulnerable children from their families.

Compared to other European countries, it is difficult to position the findings as there is no similar survey of attitudes towards foster care. With regard to foster care, research in other European Union countries focuses on the impact of foster care (and various forms of care for children) on children and the outcomes of their experience growing up outside their primary family. Family or related foster care is a child protection measure that has been advocated throughout European countries over the last decade (18). Research shows that this form of foster care meets the developmental needs of children and young people at risk better (19). Consequently, after defining attitudes towards foster care and separation of children, further research and campaigns should be conducted in Croatia to promote precisely those forms of childcare that have proven to offer more positive outcomes. 


\section{Conclusion}

The sample of respondents, consisting of education field staff and staff employed in the adult mental health care, showed slightly positive attitudes towards foster care and separation of children from the family. Respondents have the most positive attitude towards the future of separated children and do not think that separated children are doomed to a futile future. They adopt fairly uniform attitudes towards foster carers' expertise and are of the opinion that foster parents lack expertise compared to institutions.

People who are in professional contact with children have a more positive attitude towards foster care and separation of children from families than those who are not. These results are expected since people in professional contact with children have an insight into more realistic proportions of harm when it comes to violations of children's rights and health, and are therefore more likely to be aware of the need and benefit of separating children at risk from their families.

Finally, from the obtained results and their analysis in the context of similar Croatian and foreign studies, there are certain similarities, but also some interesting differences. The results, in any case, can initiate a debate on foster care in the current social context. This topic is significant because education and health employees are professionals with most often contact with children, parents, foster parents, foster children, schools and social care centers. In practice, there is a need to examine attitudes towards foster care and separation of children from the family. Therefore, this topic is essential to raise public awareness and derive positive attitudes towards foster care in order to spread the idea and practice of foster care as it has been shown to be the optimal form of care for children without parental care. Promoting positive attitudes towards foster care in a narrower and broader social context helps both foster parents and children find the best outcome in already challenging circumstances.

\section{References}

1. Ajduković M. Pristupi zbrinjavanju djece bez odgovarajuće roditeljske skrbi u Europi. Revija za socijalnu politiku. 2004;11(3-4):299-320. Croatian.

2. Ajduković M, Sladović Franz B. Samoprocjena ponašanja mladih u dječjim domovima i udomiteljskim obiteljima u Hrvatskoj. Društvena istraživanja. 2004;13(6):1031-54. Croatian.

3. Winokur M, Holtan A, Batchelder KE. Kinship care for the safety, permanency, and well-being of children removed from the home for maltreatment. Cochrane Database Syst Rev. 2014;(1):CD006546.

4. Perry KJ, Price JM. Concurrent child history and contextual predictors of children's internalizing and externalizing behavior problems in foster care. Child Youth Serv Rev. 2018;84:125-36.

5. Wu Q, White KR, Coleman KL. Effects of kinship care on behavioral problems by child age: A propensity score analysis. Child Youth Serv Rev. 2015;57:1-8.

6. Stein RE, Hurlburt MS, Heneghan AM, Zhang J, RollsReutz J, Landsverk J, et al. Health status and type of out-of-home placement: informal kinship care in an investigated sample. Acad Pediatr. 2014;14(6):559-64.

7. Stacks AM, Partridge T. Infants placed in foster care prior to their first birthday: Differences in kin and nonkin placements. Infant Ment Health J. 2011;32(5):489508.

8. Bartuloci M. Smještaj djece izvan obitelji u Republici Hrvatskoj i Smjernice za alternativnu skrb UNICEF-a. Pravnik. 2014;47(95):53-72. Croatian.

9. Glas Istre. Novi zakon o udomiteljstvu omogućit će značajan financijski iskorak za udomitelje. 2018. Available from: https://www.glasistre.hr/hrvatska/ novi-zakon-o-udomiteljstvu-omogucit-ce-znacajanfinancijski-iskorak-za-udomitelje-570790 Accessed: 10.10.2018. Croatian.

10. Kamenov Ž, Sladović Franz B, Ajduković M. Razvoj skala za ispitivanje stavova prema izdvajanju djece iz obitelji i udomiteljstvu. Hrvatska revija za rehabilitacijska istraživanja. 2006;42(1):55-76. Croatian.

11. Ajduković M, Sladović Franz B, Kamenov Ž. Stavovi stručnjaka socijalne skrbi prema izdvajanju djece iz obitelji i udomiteljstvu. Ljetopis socijalnog rada. 2005;12(1):39-66. Croatian.

12. Pennington D. Osnove socijalne psihologije. Jastrebarsko: Naklada Slap; 1996. Croatian.

13. Petz B. Psihologijski rječnik. Jastrebarsko: Naklada Slap; 2005. Croatian.

14. Rathus SA. Temelji psihologije. Jastrebarsko: Naklada Slap; 2000. Croatian.

15. Hewstone M, Strobe W. Socijalna psihologija. Jastrebarsko: Naklada Slap; 2001. Croatian. 
16. Žižak A. Udomiteljstvo djece u Hrvatskoj, analiza stanja i prijedlog smjernica. Zagreb: Unicef Ured za Hrvatsku; 2010. Croatian.

17. Centar Sirius. Analiza potreba za dodatnim osposobljavanjem pomoćnih odgajatelja, odgajatelja i udomitelja. Available from: https://centar-sirius.hr/1880-2/ Accessed: 13.10.2018. Croatian.
18. Negrão M, Moreira M., Veríssimo L, Veiga, E. Public knowledge and perceptions on family foster care: Contributes to it's development. Análise Psicológica. 2019;37(1):81-92. Portugese.

19. del Valle JF, González-García C. Intervencije za obitelji djece u sustavu alternativne skrbi u Španjolskoj. U: Knjiga sažetaka i radova Završne konferencije projekta FamResPlan. Zagreb: Edukacijsko-rehabilitacijski fakultet Sveučilišta u Zagrebu; 2019. 


\section{STAVOVI ZDRAVSTVENIH DJELATNIKA I DJELATNIKA OSNOVNIH ŠKOLA PREMA IZDVAJANJU DJECE IZ OBITELJI I UDOMITELJSTVU}

\section{Sažetak}

U Hrvatskoj je u tijeku proces deinstitucionalizacije skrbi za djecu u sklopu kojeg treba povećati smještaj djece u izvaninstitucijske oblike skrbi poput udomiteljstva. Cilj istraživanja bio je ispitati stavove prema udomiteljstvu i izdvajanju djece među školskim djelatnicima i djelatnicima sektora mentalnog zdravlja odraslih, kao i razlike u stavovima između dvije skupine stručnjaka.

Uzorak je sačinjavalo ukupno 159 ispitanika (djelatnici osnovnih škola u Kutini, Popovači i Velikoj Ludini te djelatnici Neuropsihijatrijske bolnice "Dr. Ivan Barbot" u Popovači). Istraživanjem su obuhvaćene sve relevantne sociodemografske varijable, a za ispitivanje stavova primijenjena je Skala stavova prema izdvajanju djece iz obitelji te Skala stavova prema udomiteljstvu (Kamenov, Sladović Franz i Ajduković, 2005).

$\mathrm{U}$ ispitanom uzorku stavovi o udomiteljstvu i izdvajanju blago su pozitivni, što govori da ima prostora za provođenje aktivnosti usmjerenih na osnaživanje ovih stavova. Ako bi se radilo na dodatnom osnaživanju stavova, za očekivati je i širenje populacije potencijalnih budućih udomitelja.

Važno je istaknuti ulogu zdravstvenih djelatnika koji su uključeni u skrb za mentalno zdravlje udomljene djece te razmotriti njihovu ulogu u modificiranju općih stavova prema udomljavanju djece, kao i njihovu ulogu u izgradnji optimalnog sustava udomljavanja.
Ključne riječi: stavovi, udomiteljstvo, izdvajanje djece, stručnjaci za mentalno zdravlje, školski stručnjaci 